\title{
EVIDENCE FOR SHOSHONEAN BIGHORN SHEEP TRAPPING AND EARLY HISTORIC OCCUPATION IN THE ABSAROKA MOUNTAINS OF NORTHWEST WYOMING
}

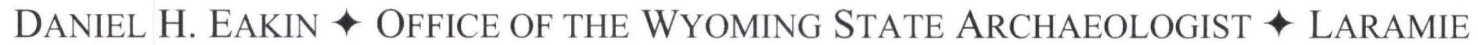

\section{$+\quad$ INTRODUCTION}

This report briefly summarizes 2004-2005 archaeological investigations at five sites located on Boulder Ridge in northwest Wyoming's Absaroka Range. Archaeological investigations on Boulder Ridge began in the 1970s when Frison (1978:258-262) documented site 48PA781, the Boulder Ridge Animal Trap (Figure 1C). In July 2003, a Northwest College (NWC) archaeological field school documented several additional sites on Boulder Ridge, including 48PA2646, a previously unrecorded feature interpreted as remains of a bighorn sheep trap (Finley and Finley 2004).

In August 2003 the Boulder Basin Wildfire burned more than 11,000 acres of Shoshone National Forest land including much of the study area. In 2004 a NWC field school re-visited the area to perform a fire damage assessment on the sites recorded the previous year. In close proximity to the feature recorded by the Finley's, the team found four sites that had escaped previous notice but had been exposed by the combustion of the forest duff layer. Two of the sites are believed to have resulted from occupation concurrent with sheep procurement activities; a site type never before documented in the archaeological record of Wyoming. The two other sites possessed unique artifact assemblages, including stone and metal tools and other Euro-American trade goods representing a very brief and poorly understood span of time known as the contact period. Efforts were made in 2005 to inventory a larger portion of the wildfire area and spend additional time investigating sites recorded in 2004. Several additional sites were located as a result of the 2005 investigations.

\section{STUDY AREA}

The study area is located in the Absaroka Mountains of northwest Wyoming (Figure 1A) and includes the mountainous and rugged terrain found in the middle reaches of Boulder and Castle creeks (Figure 1B). Prior to the 2003 fires the area was characterized by thick stands of spruce, fir and pine broken by open, grassy slopes and ridges. Elevation in the study area ranges between $2438 \mathrm{~m}$ and $3050 \mathrm{~m}$.

\section{$\downarrow$ METHODS}

Survey methods followed standard archaeological inventory procedures accepted by the State Historic Preservation Office (SHPO 2003) and the USFS. Areas of burned off duff having slopes under $30^{\circ}$ were targeted and all identifiable spring and seep areas were sought out and inspected. Due to confidentiality issues, site locations are not shown in Figure 1B. Collected artifacts are now curated at the University of Wyoming Archaeological Repository, Laramie. Richard Hughes, Geochemical Research Laboratory, performed x-ray fluorescence analysis. 


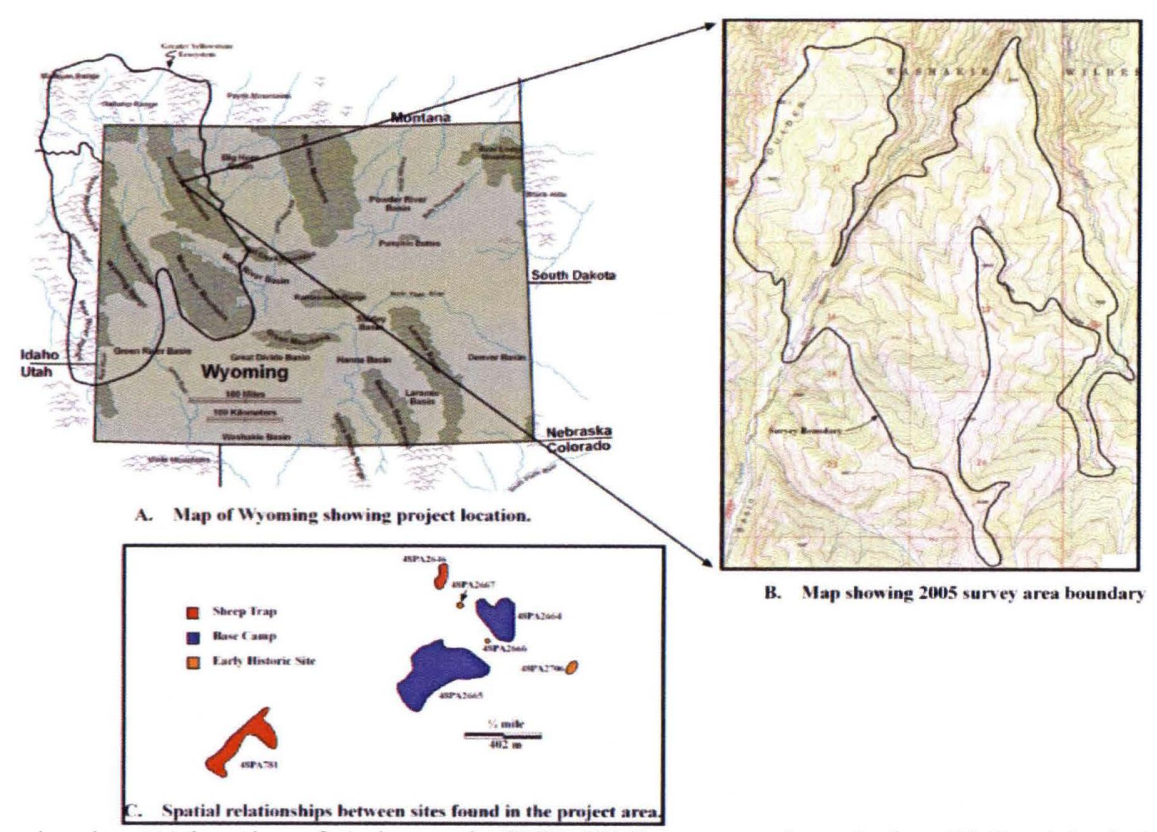

Figure 1. Map showing (A) location of study area in GYE; (B) Survey area boundaries, (C) Spatial relationships of sites discussed in this report.

\section{Background}

Although the project area lies within the traditional territory of both Crow and Shoshone Indians, several sites discussed below appear to be Shoshonean and for this reason, aspects of Shoshone ethnography, history, and archaeology are briefly reviewed. This is not to imply that the region was not used by the Crow as well as other Native American groups (Nabokov and Lorendorf 2004).

Within the historic period the Bighorn River was often considered the northeast boundary of Eastern Shoshone territory. Areas to the west, including the Yellowstone-Absaroka plateaus, upper Snake, Salmon, Missouri and Yellowstone rivers, the Wyoming Basin and peripheral northern Great Basin were used by several Shoshonean groups for subsistence, trade, and warfare (Shimkin 1986).

Ethnographic studies show that $19^{\text {th }}$ century Shoshone social structure was based on dietary mainstays, which by virtue of local environment were a general reflection of group territory (Lowie 1909, Hultkrantz 1961). Because the names carried no political affiliation, and individuals or family groups cycled from one dietary region to another, it was not uncommon for movement to lead to dietary change and a change of group name. A few commonly cited Northern Shoshone groups are: Salmon Eaters of the Snake River; Groundhog (marmot) Eaters around Boise; and the Sheep Eaters (Tukudeka) of the Idaho Sawtooths (Murphy and Murphy 1986:287). From his work with the Eastern Shoshone, Shimkin (1986: 309) discusses two groups, the Buffalo Eaters (Sage Brush People) of the Green and Wind River valleys and plains, and the Mountain Sheep Eaters (Mountaineers) of eastern Idaho, southern Montana and the GYE of northwest Wyoming. While ethnographic sources provide various amounts of information on the above groups that for the Sheep Eaters is somewhat scanty, with unclear distinctions between the Northern and Eastern Shoshone groups, and no mention of sheep trap use.

A similar situation is found in the early exploration period literature. No first or even second hand trapper or trader account mentions sheep trapping. The few references to "Sheep Eaters" or "Mountain Snakes" from these sources provide, at best, limited and inconclusive information regarding material culture, group size and range (Hughes 2000). Hopefully, the associations discussed in the following report will provide a better understanding of at least some of the high elevation animal procurement features in the GYE and the poorly understood groups responsible for their construction.

Larson and Kornfeld (1994:200-210) have reviewed the theoretical issues related to associating archaeological sites or artifact assemblages with a cultural group. They argue for recognition of a suite of "culturally diagnostic" artifacts indicative of prehistoric/early historic Shoshonean occupation in western Wyoming. The association is based on the repetitious occurrence of several artifact types, some 
of which are traceable southwestward to Shoshonean sites in the Great Basin. The artifact types include: side-and-base-notched (tri-notched) and Cottonwood triangular projectile points (see Jennings 1986:113119), Intermountain ceramic vessels (Mulloy 1958), bilaterally re-sharpened bifaces known as "Shoshone knives" (Frison 1971:269), steatite vessels and or pipes (Frison 1982), wooden structural remains including bighorn sheep and antelope traps, cribbed log structures, and conical pole lodges or "wickiups". Although some of the artifact types may be more common to some geographic areas than others, the overall artifact suite is employed here to infer Shoshonean occupation (Figure 2).

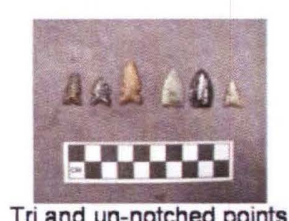

Tri and un-notched points

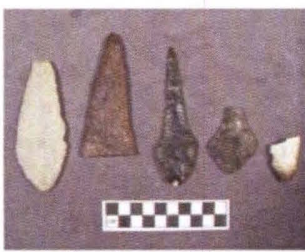

Shoshone Knives
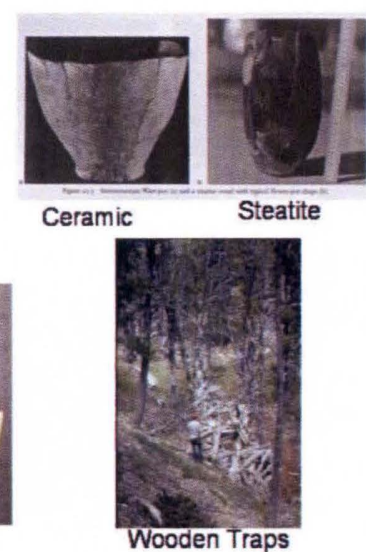

Figure 2. Artifacts diagnostic of Shoshonean occupation (After Larson and Kornfeld, 1994).

Several examples of a poorly understood artifact known as teshoa (an unhafted Shoshone woman's knife) were found at four of the five sites discussed below and may be of some importance to cultural and temporal interpretation. Shoshone women were observed using teshoa in 1872 by Joseph Leidy (1873) while on paleontological reconnaissance near Fort Bridger, Wyoming (Figure 3). Shimkin (1986:322) also mentions a "split cobble" scraper used by the Eastern Shoshone to process hides. Butler (1978) briefly mentions and provides an illustration of teshoa, but does not provide a cultural or temporal context. Eyman (1968) discusses teshoa in some detail and provides evidence that the basic design is represented as a common tool type worldwide. Perhaps more importantly teshoa are not reported from other late period Shoshonean sites in the region (Eden-Farson AD 1720 \pm 100 , Frison 1971; Level 1 of Mummy Cave AD 1610 \pm 90 , Husted and Edgar 2002, BugasHolding AD 1510 \pm 100 , Marcel Kornfeld, personal communication). In the following context teshoa may have been briefly used in a limited geographic area and could reflect an early historic or historic need for a simple, though effective and expedient tool, possibly due to an increased demand for tanned hides.

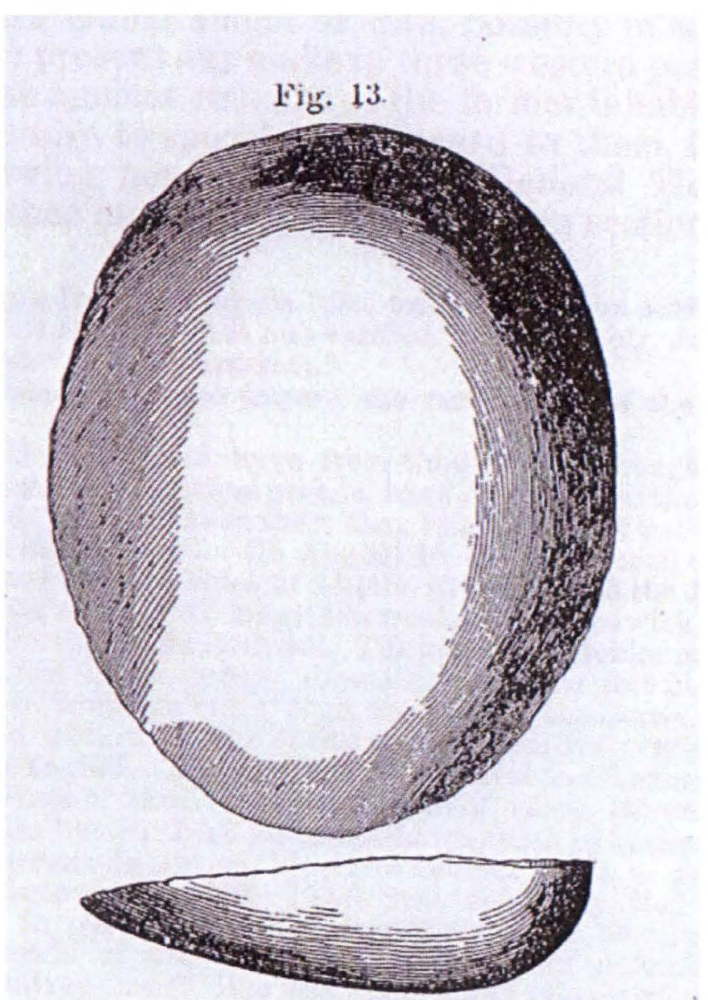

Figure 3. Illustration of a teshoa, from Leidy 1873. Caption reads "A modern stone implement of gray quartzite; a simple flake from a drift -pebble of the Uintahs. Called by the Shoshone Indians a "teshoa," and used by them as a scraper in dressing skins. Tow views: one-half size. One of half dozen similar specimens obtained from the Shoshones."

Trade items found at several sites discussed below lead to questions involving the timing of the replacement of stone tools by metal ones of Native or Euro-American manufacture. It will become apparent to the reader that the timing of the initial arrival and spread of early historic trade goods into the Rocky Mountains is poorly understood.

\section{Bighorn Sheep Traps}

Bighorn sheep traps, hunting blinds, and game fences in and around Yellowstone National Park were described as early as the 1880s (Norris 1880 ) but have continued as a focus of interest up to the present day (Clayton 1926, Honess and Frost 1942, Dominick 1964, Frison 1978, Frison et al 1990, Frison 2004). Sheep traps and related features occupy a number of topographic settings and it is highly likely that their positioning was deliberate and exploited both physical features of the landscape and the behavioral characteristics of the animals they were designed to harvest (Frison 2004). In the only systematic study to date Frison et al (1990) found that 
traps are typically made from standing or deadfall timber and rocks and have no evidence for metal tool use in their manufacture. They describe two basic designs; a possible earlier design of a simple $\mathrm{V}$ shape, and a later design that is a modified $\mathrm{V}$ or hook shape that may have employed a terminal curve to exploit the animal's tendency to flee down slope. Both types have constricting wings leading to a catch pen (Figure 4).

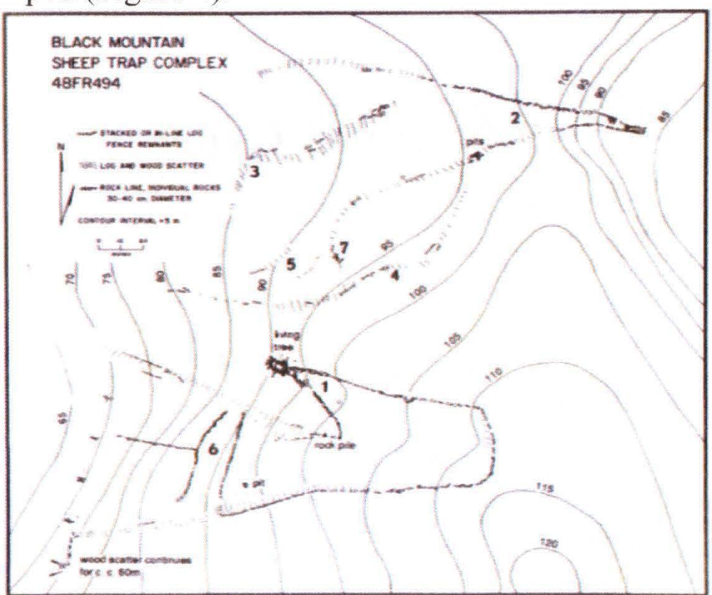

Figure 4. Sketch map, Black Mountain bighorn sheep traps. Taken from Frison et al. 1990.

Catch pens are almost always constructed from logs because of the strength necessary to hold one or two animals prior to killing. Frison (2004:158) argues that a small rise or ramp located just before the catch pen could be a diagnostic characteristic as it may have lessened the animals' tendency to spook and turn prior to jumping into the structure. Approximately $100 \mathrm{~km}$ north of the study area, in Sunlight Basin, an animal procurement feature believed to be a sheep trap was recently found (2006) that exploited a large cleft in the surrounding bedrock as a catch pen (Figure 5).

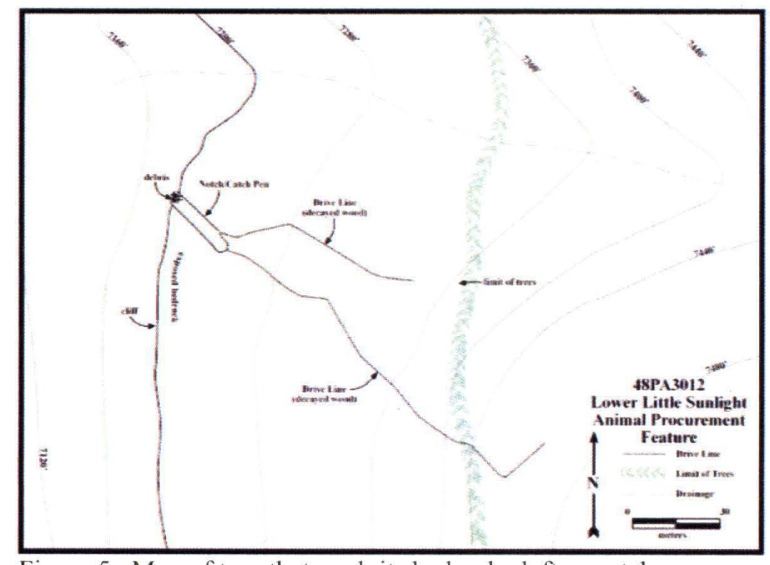

Figure 5. Map of trap that exploits bedrock cleft as catch-pen.

Frison et.al (1990) used deteriorated trap features found at high elevations represented by rock alignments and pitch-log remnants to infer a time depth of up to 500 years for this procurement strategy. In the same study, Charles Reher conducted dendrochronologic assessment of younger and betterpreserved traps from the upper Wind River Valley and estimated their age at between $\mathrm{AD} 1770$ and 1820. The procurement feature closest to the Boulder Ridge base camps (48PA2646, Figure 1C) is probably of this younger age, as portions of it are not totally weathered away and still visible (Figure 6).

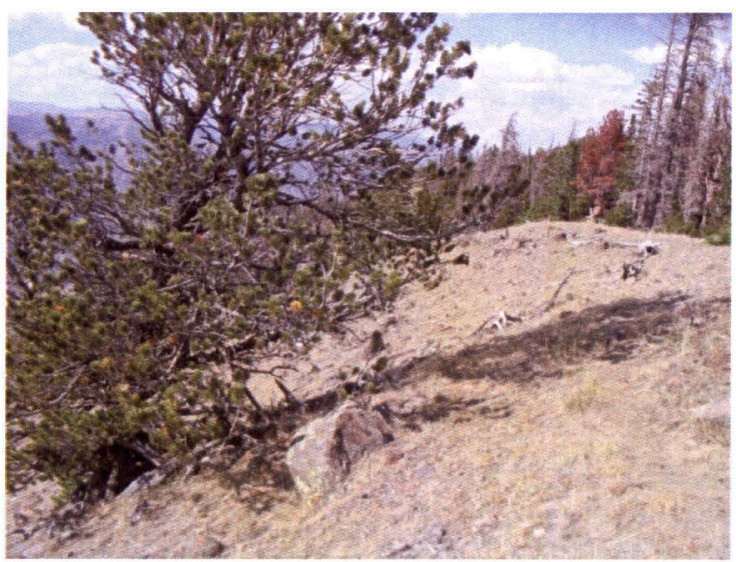

Figure 6. Photo of wing section at site 48PA2646.

Little cultural material has been found in association with bighorn sheep traps. A few ram skulls exist in museums and private collections that were evidently placed in tree branches at several traps, while one or two clubs reportedly found near traps and possibly used for dispatching animals, have also been reported (Frison 2004:161). An unknown number of bighorn sheep traps are still in existence today. The outlines of these now highly weathered and deteriorating structures probably do not convey the amount of time, effort and know-how necessary to construct and successfully operate such a feature. All are associated with old growth forest and the timber from which they are constructed is entering advanced stages of decay.

\section{$\downarrow \quad$ FINDINGS}

Approximately 1000 acres of burned area was inventoried (Figure 1B). Eight additional sites were recorded, seven of which are small, limited activity areas and are discussed in the main report of investigations. The five sites in close proximity to 48PA2646 are described here. All of these sites are considered eligible for nomination to the National Register of Historic Places. 


\section{Site: 48PA2664}

This site is a $200 \mathrm{~m} \quad \mathrm{x} 300 \mathrm{~m}$ campsite/processing area situated on a hill slope adjacent to a small spring. Artifacts consist of chipped stone and bone scatters as well as multiple hearth locations. Areas of high density chipped stone were initially encountered on the site but these disappeared within the first season of exposure, probably from unauthorized artifact collection. Artifacts of note consist of tri-notched and un-notched projectile points, bifaces, scrapers and other chipped stone tools, both complete and fragmentary teshoa, shaft abraders and carved bone disks (Figure 7). One Rose Spring point and one probable Late Archaic point indicate the site was occupied prior to the most recent episode marked by the tri-notched and un-notched projectile points. No trade items were found at this site indicating that occupations may have ceased prior to the contact period. Obsidian artifacts have been sourced to several localities including Grassy Lake $(n=1)$, Obsidian Cliff $(\mathrm{n}=3)$ in Yellowstone Park, and the Crescent $\mathrm{H}$ source $(\mathrm{n}=1)$ in Jackson Hole.

Thousands of bone fragments littered the surface of the site. Identified species include bighorn sheep, elk, medium and large artiodactyl. Part of the faunal assemblage is comprised of eight badly burned sheep crania found in close proximity to the base of a large tree, a context suggesting they were deliberately cached (Figure 8). A similar pattern involving cached skulls has been described by Frison (2004:160) from a site located on a tributary of the upper Greybull River in northwest Wyoming. The two carved bone disks were found in direct association with the sheep crania.

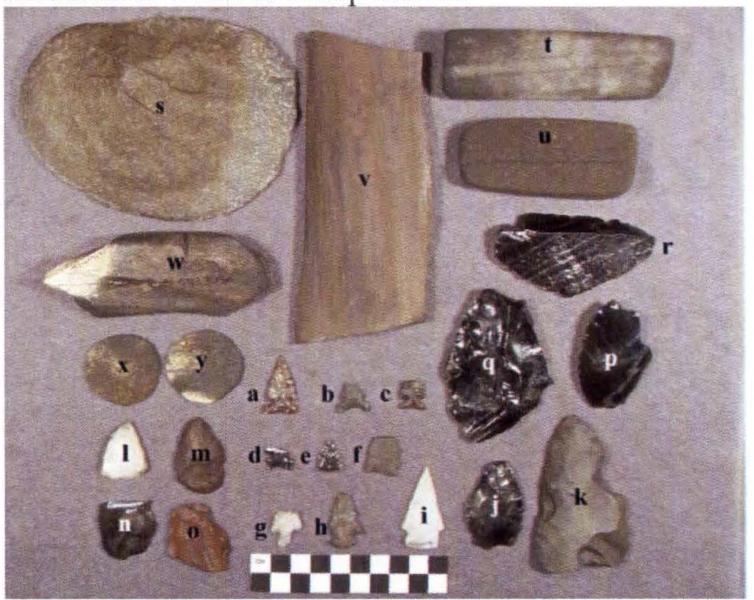

Figure 7. Selected artifacts from 48PA2664; a-d trinotched projectile points, e-f un-notched projectile points, $g$ Rose Spring point, h-i archaic points, $\mathrm{j}-\mathrm{r}$ stone tools, $\mathrm{s}$ teshoa, $\mathrm{t}$-u shaft abraders, $\mathrm{v}$ unknown tool with highly polished edge, w notched bone, $\mathrm{x}-\mathrm{y}$ carved bone disks.

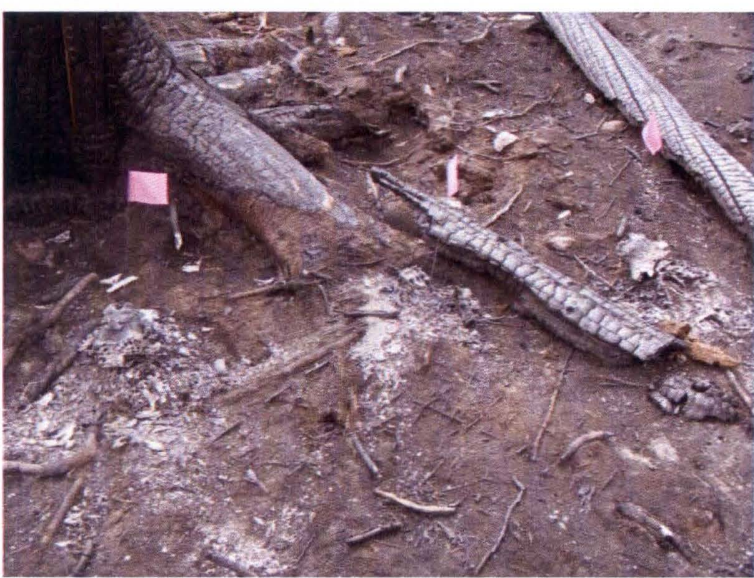

Figure 8 . Three of eight badly burned bighorn sheep skulls found near the base of a large tree at 48PA2664.

\section{Site: 48PA2665}

Site 48PA2665 is a campsite about $200 \mathrm{x}$ $200 \mathrm{~m}$ in size situated on both flat and sloped topography adjacent to a spring. Several areas containing flake, tool, or bone concentrations were observed and multiple tool caches and fire hearths were noted. High-density bone concentrations at several locations indicate probable processing areas. Other features likely represent lodge localities. A total of 142 chipped stone tools were recovered along with ground and carved stone objects, ceramics, rim fragments from a steatite vessel, and a bone flesher. Some examples of these items are shown in Figure 9.

Nearly 800 identified faunal remains represent only a fraction of the total, initially estimated in the thousands. Bighorn sheep $(n=70)$, bison $(n=16)$ and elk $(n=4)$ are represented with the most common remains being medium $(n=666)$ and large $(n=26)$ artiodactyl.

Three localities were identified as sites where lodges once existed. One of these, known as the cut-fill lodge, was created by cutting into an $18^{\circ}$ $20^{\circ}$ hillside and spreading the displaced sediment on the downhill side to create a bermed, flattened floor suitable for habitation. A similar construction pattern has been documented in the Upper Green River Basin where prehistoric Shoshonean lodges were found in association with evidence for a communal antelope kill (Frison 1971). Artifacts recovered from the cutfill lodge include a shaft abrader, a teshoa, chippedstone debitage, butchered sheep bone, a tri-notched projectile point and a broken trade bead. A second lodge locality is marked by a several meter wide circular outline of stones (Figure 10). Projectile points and a number of other tools were found within the outline while other artifacts, a flint knappers pile, 
and a complete Intermountain ceramic vessel were found just outside.

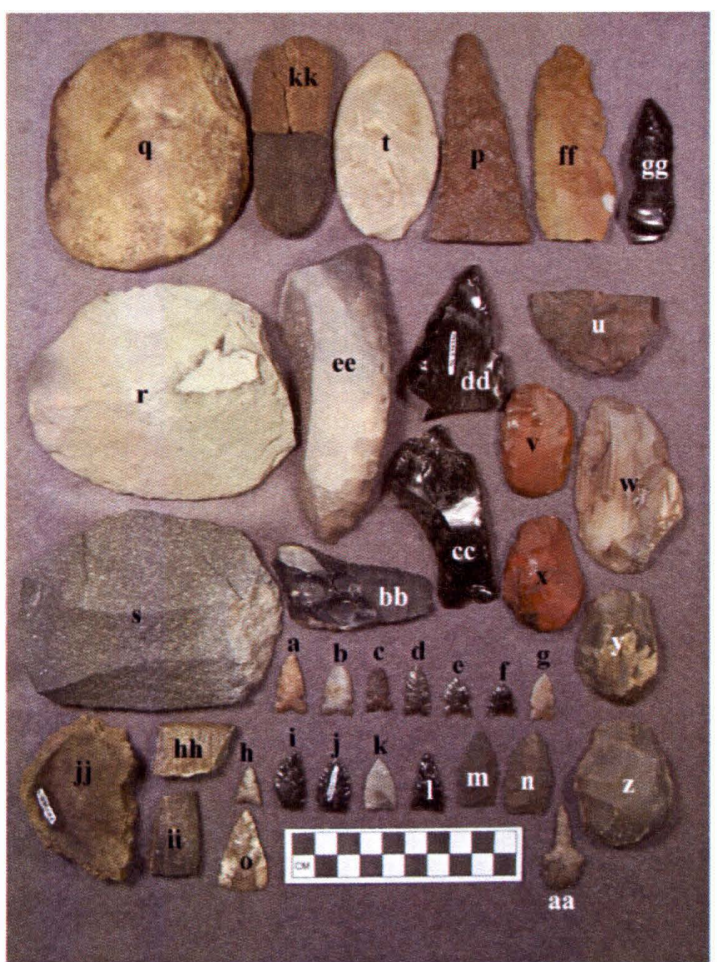

Figure 9. Selected artifacts from 48PA2665: a-g tri-notched and h1 Cottonwood Triangular projectile points, m-o point pre-forms, $p$ Shoshone knife, $\mathrm{q}-\mathrm{s}$ teshoa, $\mathrm{t}$ biface, $\mathrm{u}-\mathrm{z}$, end and side-scrapers, aa drill, bb-dd utilized flakes, ee-gg large retouched blades, hh-ii steatite vessel fragments, ji flat-bottomed Intermountain ceramic vessel, kk shaft abrader.

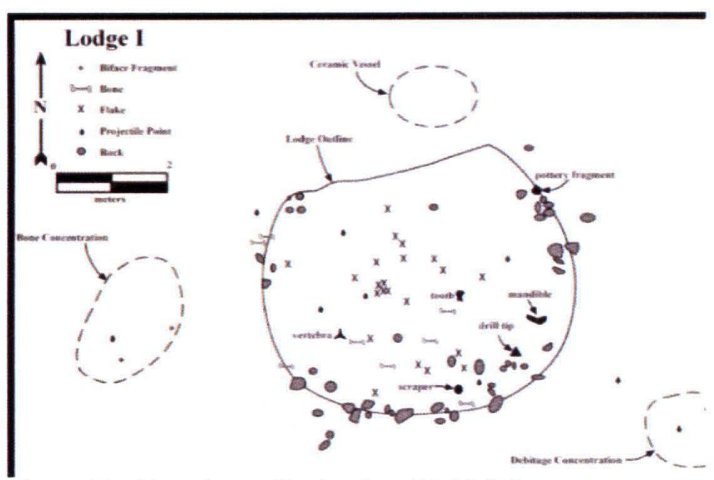

Figure 10. Plan view of Lodge I at 48PA2665

Obsidian artifacts from 48PA2665 have been sourced to Obsidian Cliff $(n=14)$, two sources in Jackson Hole $(n=16)$, Bear Gulch $(n=2)$ in eastern Idaho, and Beatys Butte $(n=1)$ in southern Oregon, approximately $800 \mathrm{~km}$ west.

Although all common artifacts found at 48PA2665 are made of stone, a small number of trade items were also present. These occurred as isolated concentrations and include the above mentioned trade bead in the lodge, two trade bead scatters (each under 10x10 m area) and another small area with several pieces of badly rusted sheet-iron and a uniquely edge abraded cobble. The overall distribution of features, artifact groupings and concentrations might suggest either 1) a pre-contact setting, as artifact classes (i.e., points, drills, scrapers, knives) are represented by stone technology, with a more limited post contact occupation superimposed later in time; or 2) an early post-contact setting when stone technology was still predominant and only limited amounts of trade goods were available in the region. The single obsidian artifact sourced to Beatys Butte Oregon may imply the use of horses.

\section{Site: 48PA2666}

This site is a small campsite approximately $10 \times 10 \mathrm{~m}$ in size and located on a low inter-stream divide. Artifacts include tri-notched and cottonwood triangular projectile points, a teshoa, a bent wire object believed to be an awl, trade beads, a "glob" of trade vermillion, a probable gun flint, a machine screw identical to types used in late $18^{\text {th }}$ and early $19^{\text {th }}$ century gunlocks, and butchered bighorn sheep bone Figure 11. The site is less than $1 \mathrm{~km}$ from 48PA2646 (Figure 1C) but there is no basis to relate the two. Although a suite of culturally diagnostic artifacts is not present, the three projectile points and the teshoa might suggest an early historic Shoshonean association. All three of the obsidian projectile points from this site have been sourced to Obsidian Cliff. Bighorn sheep bone remaining at the site can provide information pertaining to diet as well as carcass processing and treatment. The small size of the activity area may indicate use of a temporary structure. Sites of this age are rare in the region and provide information about a poorly understood period in Native American history.

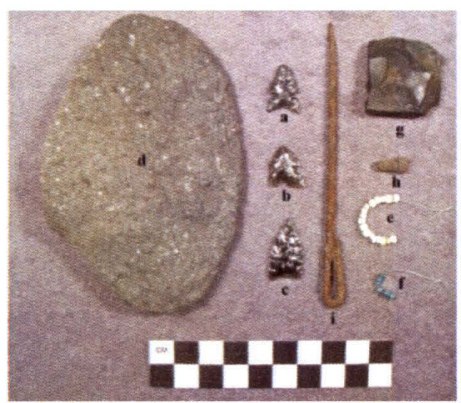

Figure 11. Selected artifacts from 48PA2666: a-c tri-notched and un-notched projectile points, $\mathrm{d}$ teshoa, e-f trade beads, g gunflint, $\mathrm{h}$ machine screw, i bent wire object.

\section{Site: 48PA2667}

This is a campsite and bighorn sheep processing area about $20 \times 20 \mathrm{~m}$ in size, situated on a 20-degree slope within about $250 \mathrm{~m}$ of site 
48PA2646 (Figure 1C). Cultural material includes hundreds of obsidian flakes, an un-notched projectile point sourced to Obsidian Cliff, four types of trade beads, sheet iron, butchered bighorn sheep $(n=20)$ and medium artiodactyl $(n=63)$ bone, and up to 200 pieces of additional unidentifiable bone of the same size class (Figure 12). Six late-term or newborn long bone shaft fragments indicate occupation coincident with the late spring lambing period. The metal items are unique as one (Figure 12b), characterized by an angular edge, could be discard generated during metal arrow point manufacture (Hansen 1972). Another (Figure 12d) could have resulted from deliberate bending or the manner in which it was cut, possibly with a chisel or shears. Together these artifacts indicate an early historic, Native American cultural context. Slope wash processes are currently re-burying the site.

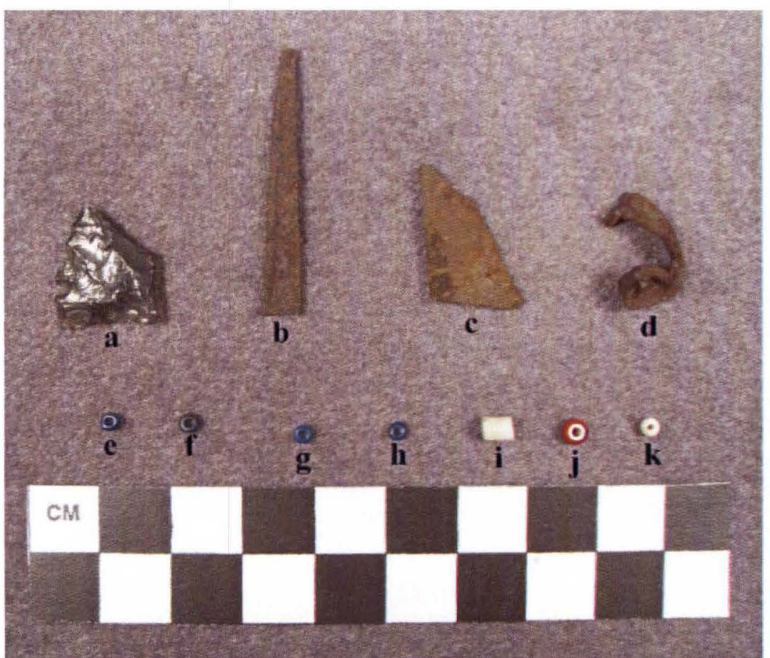

Figure 12. Selected artifacts from 48PA2667; a un-notched projectile point fragment, b- $\mathrm{d}$ cut and twisted metal, e-k trade beads.

\section{Site: 48PA2706}

This is a multi-component surface site approximately $30 \times 120 \mathrm{~m}$ in size, situated on a remote and inaccessible flat between the base of a $50^{\circ}+$ slope and the edge of a vertical canyon. Three distinct activity areas characterize the site: a lodge/artifact scatter, a chipped stone/metal-working area, and a probable dump. The Area 1 lodge is marked by a $3 \times 4 \mathrm{~m}$ outline of large tabular stones. Within the outline was found trade beads (Figure 13a) a tri-notched projectile point (Figure 13b) and a brass button (Figure 13c), along with chipped stone flakes and other stone tools. The brass button is about $7 / 8$ inch in diameter, has a smooth face, and is of the footless shank variety with no re-strike anvil seam. An embossed eagle insignia is at top center, below this and slightly off center left are stars and dots on either side of the word "BEST." The manufacturing technique of this button dates from between 1785-1800 (Olsen 1963).

Area 2 is about $12 \mathrm{~m}^{2}$ in extent and provides evidence for early historic Native American metalworking. Artifacts (Figure 13d-k) include trade beads, an un-notched projectile point, gunflint, sheet copper, three heavily edge ground and battered cobbles, approximately 10 pieces of sheet iron, chipped stone flakes and butchered sheep bone. One of these cobbles (k) shows signs of heavy abrasion, battering and divoting, indicating it was used to deliver heavy blows to a resistant cylindrical object such as an iron chisel.

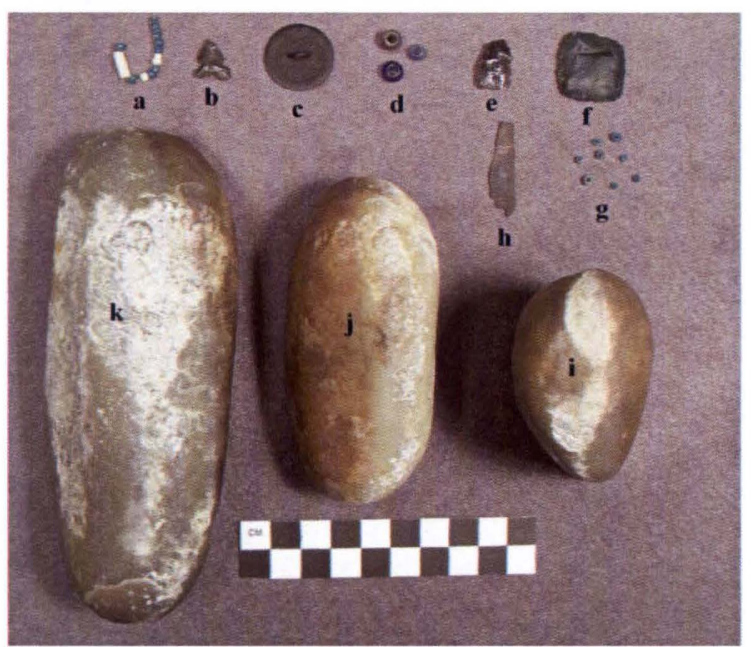

Figure 13. Selected artifacts from 48PA2706. Area 1: a trade beads, b tri-notched projectile point, c brass button, Area 2: $\mathrm{d}$ trade beads, e un-notched projectile point, f gun flint, $g$ trade beads, $h$ sheet copper, i-k edge-abraded and battered cobbles.

Area 4 is a tear-shaped, $4.5 \times 4 \mathrm{~m}^{2}$ artifact concentration located on an $18^{\circ}$ slope adjacent to an ephemeral stream cut. The shape of the concentration indicates the artifacts may have either been deliberately dumped or were in a container and were subsequently affected by slope wash processes after the container deteriorated. In addition to artifacts shown in Figure 14, about 500 trade beads, 200 chert and obsidian flakes, several vermillion globs, 30 pieces of sheet iron and wire scrap, and several additional brass tacks were found. 


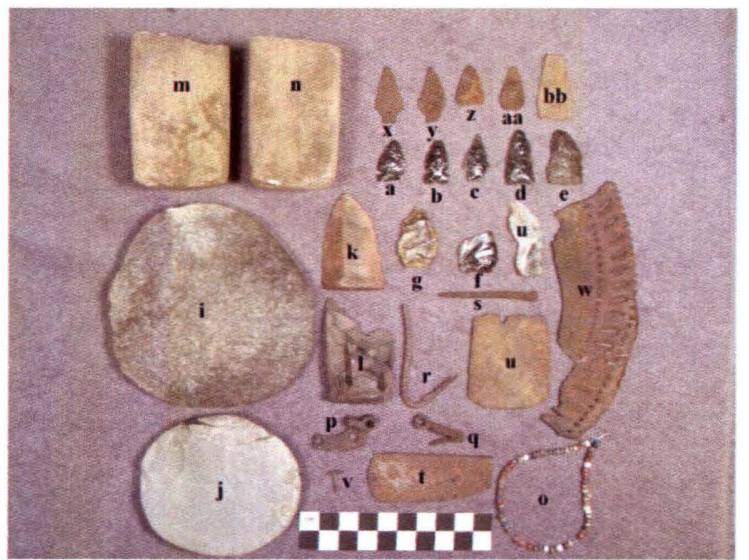

Figure 14. Selected artifacts from Area 4 48PA2706; a-c stone projectile points, $\mathrm{d}$-g stone projectile point pre-forms, $\mathrm{i}-\mathrm{j}$ teshoa, $\mathrm{k}-\mathrm{l}$ pipe pre-form, $\mathrm{m}-\mathrm{n}$ shaft abraders, o trade beads, $\mathrm{p}$ lock bridle, $\mathrm{q}$ sear return spring, $\mathrm{r}$ fishhook, $\mathrm{s}$ awl, t possible trade knife handle, $\mathrm{u}$ flesher bit, $\mathrm{v}$ brass tack, $\mathrm{w}$ punched tin plate, $\mathrm{x}$ - aa metal projectile points, bb metal projectile point pre-form.

Several trade items provide tentative age estimates. The brass tacks are square-cut with a reinforced shank/dome junction, indicating pre-1850 British manufacture (Engages 1982, Hanson 1984). Fishhooks were popular trade items from an early date (Astoria Inventories of 1813). Those manufactured prior to 1850 were similar to modern types though the shank was not eyed for line attachment (Engages 1980). Such a large hook may seem out of place in this particular setting, but as an account from a fur trader (Ross 1956) in what is today Washington state shows, Native Americans sometimes used trade items in non-traditional but creative ways.... "Wolf hunting as well as bear hunting occasionally occupies the attention of the natives...the wolf is far more difficult to decoy or entrap, being shy, guarded and suspicious. For this purpose, three cod hooks are generally tied together back to back, baited, and then fixed with a line to the branch of a tree so that the hooks are suspended in the air at the distance of four or five feet from the ground. To get hold of the bait the animal has to leap up, and the moment the hooks catch their hold it finds itself either in a standing or suspended position, which deprives the animal of its strength, neither can it in that posture cut the line; it is generally caught, sometimes dead, sometimes alive...." Alexander Ross, Spokane House, 1817 in Ross (1956).

The awl is not the common square stock, double pointed, offset trade awl (Engages 1971), but instead is circular in cross-section, pointed at one end and flattened at the other. The lock bridle and sear return spring are parts of a common side-action or bar style flint or percussion lock used from about 1800 to the 1870 s, with replacement parts still available as late as 1907 (Engages 1986). The gunflint is Indianmade from Absaroka green chert but provides little information other than that flintlocks were in use (Kenmotsu 1990). The flesher bit is about one and three-quarters inch wide and is identical to iron bits typically used in elk-horn fleshers (Hanson 1970, Shimkin 1986). The punched tin plate appears to be of non-Indian manufacture and could have originated from a number of sources. The cut edges of the tin plate and lighter-gauge metal arrow points have sharp intersecting angles consistent with those cut by scissors, a common early trade item (Astoria inventories 1813, St. Louis Mercantile Library Association 2006). The carved stone object is most likely a pipe pre-form and possesses markings consistent with having been shaped with a file. The stone may have originated locally from the contact zone between the Wiggins Formation and the Trout Peak Trachyandesite (Love and Christiansen 1985).

Artifacts recovered from 48PA2706 represent a brief period in history when the ability to work stone had not yet disappeared and the gun had not yet replaced the bow and arrow. Preliminary age estimates indicate site occupation between the earlyand mid- 1800s. The trade items certainly indicate access to a supply of Euro-American trade goods, perhaps during the Rocky Mountain fur trade period that lasted from about 1820 to 1840 . Although side and base-notched projectile points - and eight teshoa - are present, this site clearly post-dates those used by Larson and Kornfeld to illustrate their case for a diagnostic suite of Shoshonean artifacts. For this reason it may be more appropriate to classify it as early historic Native American, with Shoshonean indicators. Obsidian artifacts from the site have been sourced to Obsidian Cliff $(n=8)$ and Jackson Hole $(\mathrm{n}=1)$, as well as Packsaddle Creek $(\mathrm{n}=1)$ in the Big Hole Mountains of eastern Idaho.

\section{- CONCLUSIONS}

The archaeological discoveries within the Boulder Basin burn area bring to light a number of concerns for both archaeologists and land managers.

1) Sheep traps are the visible component of a site complex (Figure 15). The site complex can consist of an animal procurement feature, processing area, and base camp. The concept of site complex, is not new (Frison 1991:160), but is important when considering the impact of various land management practices. The Boulder Ridge sites demonstrate a high potential for processing areas or base camps not 
far from where animal procurement features are known to exist.

Climatic patterns believed related to an increase in wildfire frequency since the $1980 \mathrm{~s}$ in the western U.S. may lead to continued declines in forest health (Westerling et al 2006). The lack of post-fire cultural resource investigation in wildfire areas has probably resulted in a loss of information related to prehistoric use of high-elevation environments and may result in more loss in the future. Post-burn cultural resource inventories can provide a basis to amend land management policy to reflect the longterm obligation of management agencies.

2) Forest floor duff, otherwise known as the O horizon (Birkeland 1984), is a viable burial medium for archaeological sites in forested environments. Ground visibility in forested environments is problematic for archaeologists because vegetation and the $\mathrm{O}$ horizon conceal artifacts and features that form the basis of archaeological site identification. Site visibility in forested environments influences management decisions related to timber harvesting, controlled burns, and post-fire management of natural burns.

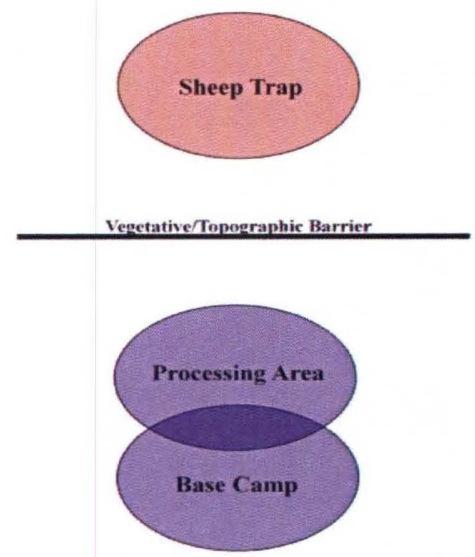

Figure 15. Model of bighorn sheep trap site complex.

3) The suite of culturally diagnostic artifacts from 48PA2664 and 48PA2665 strengthen arguments for the Shoshonean origin of wooden animal procurement features on Boulder Ridge and other areas. Although their place in the material culture remains unclear, the teshoa described in this report are associated with a generally accepted suite of artifacts that indicate a Shoshonean affiliation. The ties may be reinforced by Leidy's 1870 s observation in the upper Green River Basin, as well as Shimkin's reported use by the "Plains" Shoshone. For the Boulder Ridge sites the presence of teshoa in a protohistoric/pre-contact association and an early historic/post contact association suggests their use was very late and short-lived.

4) Artifact assemblages from the two base campsites indicate Shoshonean groups living in highelevation, warm-season settings shared a closely related material culture - including identical projectile point and Shoshone knife styles, Intermountain ceramics and steatite use - with Shoshonean groups living in lower-elevation settings at other times of the year. In addition, the geographic range implied by the Boulder Ridge obsidian sourcing, sheep trap occurrences, steatite, and teshoa indicate that Shoshonean "Sheep Eater" groups shared common cultural traits and subsistence strategies encompassing a wide area. Over the course of several seasons these groups would have exploited food types that would potentially identify them with other group names (Figure 16). This pattern is consistent with the ethno-historically based models of a relatively homogeneous inter-regional Shoshonean adaptation (Murphy and Murphy 1986, Shimkin 1986) and may outline pre-contact group ranges that became disrupted after historic contact.

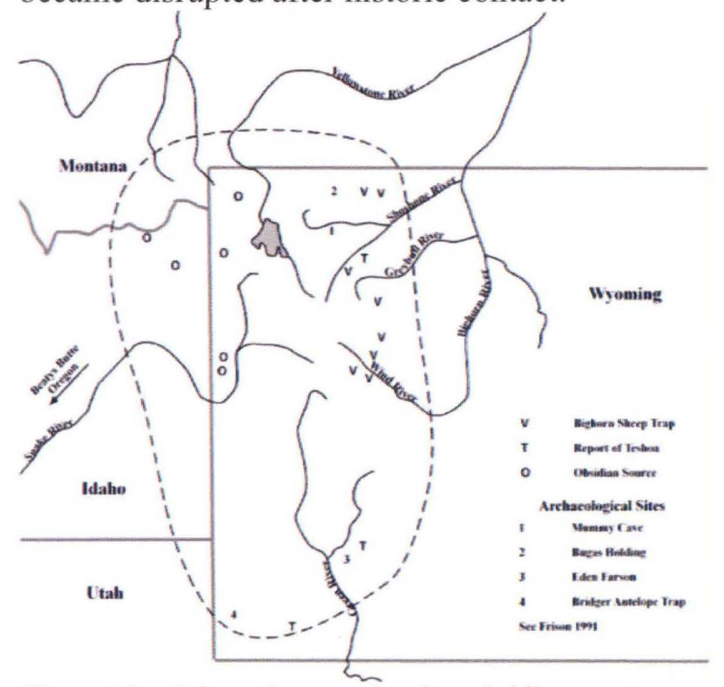

Figure 16. Schematic map showing obsidian sources, wooden traps, and selected archaeological sites mentioned in this report. Dashed line shows inferred range of groups sharing similar subsistence practices.

5) The three early historic sites (PA2666, PA2667, PA2706) represent rare occurrences in the archaeological record of the Central Rocky Mountains. Based on this brief analysis, they could date from as early as the late 1700 s to as late as 1850 . Native American archaeological sites representing the early $19^{\text {th }}$ century are few; with finds often from poor contexts such as a grass-roots zone, or the churned floor of a cave or rock shelter. Although it is well accepted that trade goods were diffused in advance of the first Euro-American traders and 
explorers, very few primary accounts describe the early contact-period native culture of the Rocky Mountains. Lewis and Clark's account is one of the best, in light of the above cultural and temporal contexts, as they chronicle a surprising number of Euro-American items in possession of a group of Upper Salmon River (Lemhi) Shoshone at a time (August 23, 1805) well before the heyday of the Rocky Mountain fur trade:

"The metal which we found in possession of these people consi[s]ted of a few indifferent knives, a few brass kettles some arm bands of iron and brass, a few buttons, woarn (sic) as ornaments in their hair, a spear or two of a foot in length and some iron and brass arrow points which they imformed (sic) me they obtained in exchange for horses from the Crow or Rocky Mountain Indians on the yellowstone River. the bridlebits and stirreps (sic) they obtained from the Spanyards (sic), tho these were but few. many of them made use of flint for knives, and with this instrument, skined (sic) the animals they killed, dressed their fish and made their arrows; in short they used it fir (sic) every purpose to which the knife is applied. this flint is of no regular form, and if they can only obtain a part of it, an inch or two in length that will cut they are satisfied. they renew the edge by flecking off the flint by means of the point of an Elk's or deer's horn. with the point of a deer or Elk's horn they also form their arrow points of the flint, with a quickness and neatness that is really astonishing. we found no axes or hatches among them; what wood they cut was done either with a stone or Elk's horn.the latter they use always to rive or split their wood. their culinary eutensils (sic) exclusive of the brass kettle before mentioned consist of pots in the form of a jar made either of earth [ceramic], or of a white soft stone [steatite] which becomes black and very hard by birning (sic), and is found in the hills near the three forks of the Missouri between Madison's and Gallitin's (sic) rivers" (Thwaites 1905:19).

6) Native metal working, including handhammering metal and smoothing with stone tools to produce lance or projectile points, has been inferred from surface finds (Frison 1991:123, Crabtree 1968). Three of the five sites discussed above possess either direct or indirect evidence for such activity, indicating that it was a relatively common practice, although a short-lived one, which contributed to the ultimate replacement of stone technology.

7) Relationships between the two animal procurement features on Boulder Ridge and the two base camp occupations may never be firmly understood. The three small, early historic camps are located away from and appear to post-date the larger base camps. When combined, the occupations may imply multi-generational familiarity with the area, as possibly learned through descent, and represent reoccupation of a favored area, whose use, perhaps within a certain band, extended into the Prehistoric period.

\section{$\downarrow$ EPILOGUE}

Through a grant from Indiana University's New Frontiers in the Arts and Humanities, archaeological research continued on Boulder Ridge during the summer of 2006 . Under a cooperative agreement between the Shoshone National Forest and the Office of the Wyoming State Archaeologist, Dr. Laura Scheiber (Indiana University) and Judson Finley (Washington State University) led a team of students from Indiana University, Northwest College (Powell, Wyoming), the Universities of Utah, Oregon, Montana, and the American University in Washington D.C. The fieldwork combined surveygrade EDM and GPS equipment and in-field attribute-based artifact analysis to map more than 1500 artifact clusters at 48PA2665 and over 800 surface artifacts at 48PA2706.

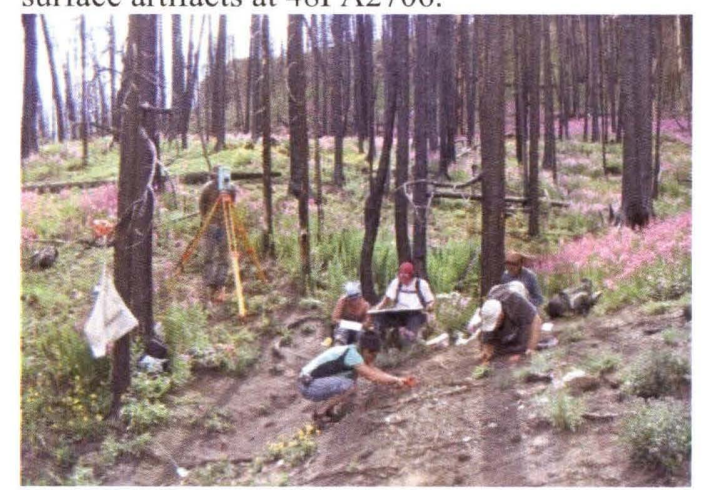

Mapping and recording artifacts at 48PA2706. Left to Right: Jake Enk, Laura Scheiber, Sara Newman, Gina Zavala, Judson Finley, Ashley Howder; photo by Dan Eakin

\section{ACKNOWLEDGMENTS}

A debt of gratitude is owed to a number of organizations for their assistance thus far in the Boulder Ridge area. These include the University of Wyoming/National Park Service Research Center, Wyoming Department of State Parks and Cultural Resources/Office of the Wyoming State Archaeologist, Shoshone National Forest, Northwest College, Bighorn Canyon National Recreation Area, 
National Park Service, Wyoming Archaeological Society, and Lee Livingston Outfitters. Individuals contributing time to the project include Chris Finley, Vickie Finley, Forrest Green, George Frison, Julie Eakin, Ann Johnson, Crystal Hazen, Tim Brown, Brandi Jessup, Richard Adams, John Laughlin, Ardeth Hahn, Jud Finley, Laura Scheiber, Marcel Kornfeld, Allen Madril, John Allen, Roger Green, Steve Potter, and Steve Rhonne.

\section{$\downarrow$ Literature Cited}

Astoria Inventories. 1813. Inventory of Sundries delivered to the Northwest Company, Astoria, Columbia River, October, 1813. www.xmission.com/astoria

Birkeland, P.W. 1984. Soils and Geomporphology. Oxford University Press, New York.

Butler, R.B. 1978. A guide to understanding Idaho Archaeology (Third Edition): The upper Snake and Salmon River Country. Idaho State Historic Preservation Office, Boise, Idaho.

Clayton, A.G. 1926. A brief history of the WashakieNational Forest and the duties and some experiences of a ranger. Annals of Wyoming. 4:2, pp. 278-311.

Crabtree, D.E. 1968. Archaeological evidence of acculturation along the Oregon Trail. Tebiwa. 11: 2, pp. 38-42.

Dominick, D. 1964. The Sheepeaters. Annals of Wyoming 36:2: 131-168.

Engage's

1971. Indian Awls. The Museum of the Fur Trade Quarterly, Vol. 7, No. 2, pp.2-3.

1980. Fish Hooks. The Museum of the Fur Trade Quarterly. 16:.4, pp. 8-11.

1982. Brass Tacks. The Museum of the Fur Trade Quarterly 18: 1-2, pp. 20-22.

1986. Not-So-Old Rifle Locks. The Museum of the Fur Trade Quarterly.2:4, pp.11-12.

Eyman, F.1968. The Teshoa, a Shoshonean Woman's Knife: A study of American Indian Chopper
Industries. Pennsylvania Archaeologist 34, 3-4.

Finley, J.B. and C.C. Finley. 2004. The Boulder Ridge Archaeological Inventory: A Late Prehistoric/Early Historic Shoshone Landscape in Northwestern Wyoming. A report prepared for the USDA Shoshone National Forest, Cody, Wyoming. Northwest College Department of Anthropology Technical Report Series No. 1A, Northwest College, Powell, Wyoming. Report on file at the Shoshone National Forest Office, Cody, Wyoming.

Frison, G.C. 1971. Shoshonean antelope procurement in the upper Green River Basin, Wyoming. Plains Anthropologist 16(54):258-84.

Frison, G.C. 1978. Prehistoric Hunters of the High Plains. New York: Academic Press.

Frison, G.C.1982. Sources of steatite and methods of prehistoric procurement and use in Wyoming. Plains Anthropologist 27(98):273-286.

Frison, G.C. 1983. The Lookingbill Site, Wyoming 48FR308. Tebiwa 20:1-16.

Frison, G.C. 1991. Prehistoric Hunters of the High Plains $2^{\text {nd }}$ edition. New York: Academic Press.

Frison, G.C. 2004. Survival by Hunting: Prehistoric Human Predators and Animal Prey. University of California Press, Berkeley.

Frison, G.C., C.A. Reher, and D.N. Walker. 1990. Prehistoric Mountain Sheep hunting in the central Rocky Mountains of North America. In Hunters of the Recent Past, edited by L. B. Davis and B. O. K. Reeves. London: Unwin-Hyman. Pp. 208-240.

Hanson, C., Jr. 1984 British Hardware for the Trade. The Museum of the Fur Trade Quarterly 20: 3, pp.1-8.

Hanson, J. 1970. Elkhorn scraper bits. The Museum of the Fur Trade Quarterly 6:3, pp.7-10.

1972 Upper Missouri Arrow Points. The Museum of the Fur Trade Quarterly. 8:4, pp. 2-8. 
Honess, R, and N. Frost. 1942. A Wyoming Bighorn Sheep Study. Wyoming Game and Fish Department Bulletin No. 1 .

Hughes, S. 2000. The Sheepeater Myth of Northwestern Wyoming. Plains Anthropologist 45:171. 63-83.

Hultkrantz, A. 1961. The Shoshones in the Rocky Mountain Region. Annals of Wyoming $33: 1 .: 19-40$.

Husted, W. and R. Edgar. 2002. The Archaeology of Mummy Cave, Wyoming: An introduction to Shoshonean Prehistory. National Park Service, Midwest Archaeological Center and Southeast Archaeological Center, Special Report No. 4, Technical Reports Series No. 9.

Jennings, J. 1986. Prehistory: Introduction. In Handbook of North American Indians: Volume 11, the Great Basin. Ed. William C. Sturtevant (general) and Warren L D’Azevedo pp. 113-119. Smithsonian Institution, Washington.

Kenmotsu, N. 1990. Gunflints: A study. Journal of the Society for Historical Archaeology. 24:.2, pp.92-124.

Larson M.L. and M. Kornfeld. 1994. Betwixt and Between the Basin and the Plains: The Limits of Numic expansion. In Across the West: Human Population Movement and the Expansion of the Numa. pp 200-210. Edited by David Madsen and David Rhode. University of Utah Press, Salt Lake City.

Leidy, J. 1873. On Remains of Primitive Art in the Bridger Basin of Southern Wyoming. In: $A$ Geological and Geographical Survey of the Territories, $6^{\text {th }}$ Annual Report, edited by F.V. Hayden, pp. 651-54, pls. 7-12. Washington

Love, J.D. and A.C. Christiansen. 1985.Geologic Map of Wyoming. U.S. Geological Survey, Denver.

Lowie, R.H. 1909. The Northern Shoshone. Anthropological Papers of the American Museum of Natural History. VII, Part II. New York.
Mulloy, W.T. 1958. A preliminary historical outline for the Northwestern Plains. University of Wyoming Publications 22(1):1-235.

Murphy, R.F. and Y. Murphy. 1986. Northern Shoshone and Bannock. In Handbook of North American Indians: Volume 11, the Great Basin. Eds. William C. Sturtevant (general) and Warren L D'Azevedo (Volume) pp. 284-307. Smithsonian Institution, Washington.

Nabokov, P. and L. Loendorf. 2004. Restoring a Presence: American Indians and Yellowstone National Park. University of Oklahoma Press, Norman.

Norris, P.W.

1880 Report Upon the Yellowstone National Park, to the Secretary of the Interior, for the year 1879. Government Printing Office, Washington, D.C.

Olsen, S.J. 1963. Dating early plain buttons by their form. American Antiquity vol. 28, no. 4, pp. 551-554.

Ross, A. 1956. The fur hunters of the far west. Edited by Kenneth A Spaulding. University of Oklahoma Press: Norman.

Shimkin, D.B. 1986. Eastern Shoshone. In Handbook of North American Indians: Volume 11, the Great Basin. Edited by William C. Sturtevant (general) and Warren L D’Azevedo (Volume) pp. 308-335. Smithsonian Institution, Washington

SHPO (State Historic Preservation Office.).2003. Draft Wyoming State Historic Preservation Office Format, Guidelines, and Standards for Class II and III Reports. http://wyoshpo.state.wy.us/shpoweb2002/20 02webpages/class 3 .htm

St. Louis Mercantile Library Association. 2006. Robert Campbell's accounts from 1832. From: Papers of the St. Louis Fur Trade, Part 3: Robert Campbell Family Collection. Transcribed by Bill Nevius, St. Louis Mercantile Library Association, St. Louis, Misssouri. www.xmission.com/campacct 
Steward, J.

1938. Basin-Plateau aboriginal sociopolitical groups. Bureau of American Ethnology Bulletin No. 120.

1943. Culture element distributions:XXIII, Northern and Goshiute Shoshoni. Anthropological Records 8:3. University of California Press, Berkeley.

Stuart, R. 1935. The Discovery of the Oregon Trail. Edited by Philop Ashton Rollins. New York:Charles Scribner's Sons.
Thwaites, R.G., ed.. 1905. Original Journals of the Lewis and Clark Expedition, 1804-1806. Volume 3. New York: Dodd, Mead and Company.

Westerling, A.L., H.G. Hidalgo, D.R. Cayan and T.W Swetnam.. 2006. Warming and earlier spring increase western U.S. forest wildfire activity. Science 313(5789): 940-943. 